Hans W. Nijman $\triangle \triangle$,

Jos G. A. Houbiers ${ }^{\circ}$,

Michel P. M. Vierboom,

Sjoerd H. van der Burg,

Jan W. Drijfhout ${ }^{\circ}$, Joe D'Amaro ${ }^{\circ}$,

Peter Kenemans ,

Cornelis J. M. Melief and

W. Martin Kast

Department of Immunohematology and Blood Bank, University

Hospital $^{\circ}$, Leiden and Department of Obstetrics and Gynecology, Free University Hospital . Amsterdam

\section{Identification of peptide sequences that potentially trigger HLA-A2.1-restricted cytotoxic T lymphocytes*}

\begin{abstract}
We used the human processing defective cell line 174CEM.T2(T2) to identify potential cytotoxicT lymphocyte (CTL) epitopes of human proteins. Exogenously added peptides can increase the number of properly folded HLA-A2.1 molecules on the cell surface of T2 cells, as shown by immunofluorescence measurements using the mouse monoclonal antibody BB7.2 (anti-HLA-A2.1) and fluorescein isothiocyanate-labeled goat anti-mouse $F\left(a b^{\prime}\right) 2$ antibody. The peptides were selected on the basis of a computer score derived from the recently described HLA-A2.1 specific motif. Analysis of the influenza matrix protein showed that 15 out of 35 high-scoring peptides up-regulate the expression of HLA-A2.1 molecules on the T2 cell surface. The combination of the computer scoring program and an immunofluorescence-based peptide binding assay allows rapid detection of potential CTL target peptides.
\end{abstract}

\section{Introduction}

The MHC gene products associate with peptides and are recognized by cytotoxic T lymphocytes (CTL) [1]. Class I molecules are membrane heterodimers composed of a 45-kDa heavy $(\mathrm{H})$ chain noncovalently associated with an invariant light chain, $\beta_{2}$-microglobulin $\left(\beta_{2} \mathrm{~m}\right)$. The $\mathrm{H}$ chain has three extracellular domains: $\alpha 1, \alpha_{2}$ and $\alpha_{3}$. The amino-terminal al and $\alpha 2$ domains interact with each other to form a peptide-binding groove, while the a3 domain adjacent to the plasma membrane directly contacts fern [2] The $\mathrm{H}$ chains associate with $\beta_{2} \mathrm{~m}$ shortly after synthesis in the endoplasmic reticulum (ER) [3]. Assembly of the $\mathrm{H}$ chain with $\beta_{2} \mathrm{~m}$ and peptide is required for conformational stability and presentation at the cell surface of peptides [4-7]. Proteins present in the cytosol appear to be cleaved into fragments of 8-11 amino acids [8, 9]. The class 1 molecules are, on their way to the cell surface, loaded with peptide in or between the ER and the Golgi complex [10-13].

Recent studies have identified mouse and human cell lines, designated RMA-S [4], 721.174 [14] and 174CEM.T2 (T2) [15], which produce abundant cytoplasmic $\mathrm{H}$ chains and $\beta_{2} \mathrm{~m}$, but present low amounts of surface MHC molecules. These so-called processing-defective cell lines are unable to present endogenously synthesized peptides to CTL $[4,16]$. The processing defect in the T2 cell line is due to a homozygous deletion of the MHC class II region located on chromosome 6 including the TAP1 and TAP2 (transporters associated with antigen processing) genes which encode the transporter proteins [17]. The HLA-A2.1 molecules are the

\section{[I 11167]}

\footnotetext{
* This work was partially supported by the Praeventiefonds.

- Fellow of the Royal Netherlands Academy of Arts and Sciences (KNAW).
}

Correspondence: W. Martin Kast. Department of Immunohematology and Blood Bank, University Hospital, P.O. Box 9600. NL-2300 RC Leiden, The Netherlands

Key words: Cytotoxic T lymphocytes / Influenza matrix protein / Epitope identification / Processing defective cell line only HLA molecules present, at low density, on the cell surface of the T2 cell line and are at least partially occupied by peptides derived from the signal peptide domains of normal cellular proteins (IP-30, calreticuline) $[18-20]$.

The 721.174 cells present exogenously added peptides which can bind to HLA-A2.1 at relatively high levels despite the relatively low levels of steady state expression of cell surface HLA-A2.1 molecules [21]. We used the T2 line, a cell line with the same processing defect as 721.174 cells, to identify peptide binding to HLA-A2.1 by measuring the HLA-A2.1 cell surface expression. The peptides used in our tests were selected using a computer scoring program derived from the HLA-A2.1 peptide motif $([22] ; \bullet)$. We chose to study the influenza matrix protein because a previously described influenza matrix-specific HLA-A2.1-restricted CTL clone recognizes a defined influenza matrix epitope [23. 24] which we expected to detect in our test system.

\section{Materials and methods}

\subsection{Scoring system}

Sequencing of peptides eluted from purified HLA-A2.1 molecules revealed an HLA-A2.1 allele-specific peptide motif $[20,22]$. It includes peptides with a length of nine amino acids with two anchor residues, a leucine, isoleucine or methionine at position 2 and a hydrophobic aliphatic residue at position 9, the $\mathrm{C}$-terminal residue. The term anchor residue was used for the positions revealing a strong signal for only one amino acid or a few amino acids with closely related side chains. Furthermore. "strong and weak" amino acids are described in the different positions. We developed our own computer scoring program deduced from the HLA-A2. 1 peptide motif. We scored six points for an anchor residue, four points for a strong and two points for a weak residue. The score for a given peptide is obtained

- D'Amaro. J.. Melief, C. J. M.. Schipper, R. and Kast. W. M.. A computer program for predicting possible CTL epitopes based on MHC class I peptide motifs: to be submitted for publication. 
by multiplication of the scores for each amino acid position. In this way the maximum score for a peptide of a length of nine amino acids is 36864 points $\left(6^{2}\right.$ points $\times 4^{3}$ points $\times 2^{4}$ points). Peptides lacking anchor residues at position 2 and at the C-terminal end were discarded. Peptides longer than nine amino acids can also bind to MHC molecules depending on the sequence [25]. Therefore, the computer program also scores for peptides with a second anchor residue at position 10 or 11 .

\subsection{Peptide binding study}

Peptides were synthesized by solid-phase strategies on an automated multiple peptide synthesizer (Abimed AMS 422) using Fmoc chemistry. The purity of the peptides was determined by reverse-phase HPLC. Peptides were dissolved in DMSO (final DMSO concentration $0.25 \%$ ) and diluted in $0.9 \% \mathrm{NaCl}$ to apeptide concentration of $2 \mathrm{nig} / \mathrm{ml}$ and stored at $-20^{\circ} \mathrm{C}$. The $\mathrm{T} 2$ cell line, a gift from Dr. P. Cresswell (Dept. of Immunology, Yale University, New Haven, CT), was cultured in Iscove's modified Dulbecco's medium (IMDM) (Biochrom KG, Seromed Berlin, FRG) with $2 \mathrm{mM}$ glutamine, $100 \mathrm{IU} / \mathrm{ml}$ penicillin, $100 \mathrm{ug} / \mathrm{ml}$ kanamycin and $10 \%$ fetal calf serum (FCS, Hyclone Laboratories Inc. Logan, UT). The T2 cells were washed twice in serum-free culture medium. Cells $(80000)$ in $40 \mathrm{ul}$ serum-free medium were put into a V-bottom 96-well plate together with $10 \mathrm{ul}$ of the peptide dilution at different concentrations or $10 \mathrm{ul} 0.9 \% \mathrm{NaCl}$, and incubated overnight at $37^{\circ} \mathrm{C}, 5 \% \mathrm{CO}_{2}$ in humidified air. The cells were washed once with cold $\left(4^{\circ} \mathrm{C}\right)$ "PBA" $(0.9 \% \mathrm{NaCl}, 0.5 \%$ BSA, $0.02 \% \mathrm{NaN}_{3}$ ) and stained by indirect immunofluorescence. The first antibody BB7.2 (HLA-A2.1-specific monoclonal antibody) was added in a saturating amount and incubated for $30 \mathrm{~min}$ at $4{ }^{\circ} \mathrm{C}$. After two washing steps with cold PBA, FITC-labeled $\mathrm{F}\left(\mathrm{ab}^{\prime}\right)_{2}$ fragments of goat anti-mouse IgG (Tago Inc. Burlinger, CA) in a dilution of 1: 40 were added as the second antibody and incubated for another $30 \mathrm{~min}$ at $4{ }^{\circ} \mathrm{C}$. The cells were washed once and fluorescence was measured at $488 \mathrm{~nm}$ on a FACScan flow cytometer (Becton Dickinson, Franklin Lakes, NJ).

The fluorescence ratio (FR) was calculated with the formula: mean fluorescence experimental sample / mean fluorescence background.

Human $\beta_{2} m$ (Sigma, St. Louis, MO) was dissolved in serum-free IMDM and stored at $-20^{\circ} \mathrm{C}$ at a concentration of $1 \mathrm{mg} / \mathrm{ml}$. Human $\beta_{2} \mathrm{~m}$ was used during the incubation period of the $\mathrm{T} 2$ cells with the peptide.

\subsection{Competition cytotoxicity assay}

The influenza matrix-specific HLA-A2.1-restricted CTL clone was a generous gift from Dr. H. Spits (DNAX, Palo Alto, CA). The CTL clone was grown on HLA-A2.1positive EBV-transformedB cell lines irradiated with $30 \mathrm{~Gy}$ in RPMI (Gibco Paisley, Scotland) with $2 \mathrm{~mm}$ glutamine, $100 \mathrm{lU} / \mathrm{ml}$ penicillin, $100 \mu \mathrm{g} / \mathrm{ml}$ kanamycin and $10 \% \mathrm{FCS}$ (Hyclone Laboratories). In the competition cytotoxicity assay $2000{ }^{51} \mathrm{Cr}$-labeled T2 cells $(25 \mu$ l complete IMDM medium/well) were incubated with $5 \mathrm{ul}$ of the influenza CTL epitope $(0.5 \mathrm{ug} / \mathrm{ml}$, final concentration $)$ in the pre- sence or absence of $5 \mathrm{ul}$ of one of the competitor synthetic peptides $(20 \mathrm{ug} / \mathrm{ml}$, final concentration) in a U-bottom 96-well plate. After $20 \mathrm{~min}$ of incubation the influenzaspecific CTL clone was added in a volume of $25 \boldsymbol{u l}$ of complete IMDM medium at an effector to target ratio of $5: 1$ for an additional $4 \mathrm{~h}$. The percentage ${ }^{51} \mathrm{Cr}$ release was calculated with the formula: [(cpm experimental well background ${ }^{51} \mathrm{Cr}$ release) / (maximum ${ }^{51} \mathrm{Cr}$ release background ${ }^{51} \mathrm{Cr}$ release)] x 100.

The background was always less than $25 \%$ of maximal release. The percentage blocking was calculated with the formula: $\left[1-\left(\%{ }^{51}\right.\right.$ Crrelease oftarget cells incubated with epitope and competitor peptide / \% ${ }^{51} \mathrm{Cr}$ release of target cells incubated with epitope)] x 100.

\section{Results}

\subsection{Scoring system}

Fig. 1 illustrates the score distribution for peptides of the influenza matrix protein using a computer scoring program, the highest score was 1152 points. Peptides with anchor residues at position 2 and the C-terminal end were selected for synthesis (Tables 1 and 2). Eighteen peptides chosen randomly $i$.e. not according to the selection rules, were used as control peptides (Table 3 ). The influenza matrix epitope recognized by a HLA-A2.1-restricted CTL is one of the selected peptides with a high score (seq. no. 58-66; 576 points, Table 1). The computer scoring program revealed only 35 peptides ( $8 \%$ of the total number, Table 1 ) with a relatively high score of 144 points or higher, which makes it a useful first step in finding potential CTL epitopes. Peptides with anchor residues at position 2 and the C-terminal end with a score lower than 144 points are depicted in Table 2.

\subsection{Peptide binding assay}

Out of 35 high-scoring influenza matrix peptides, including the nonamer 58-66, 15 up-regulated the HLA-A2.1 mole-

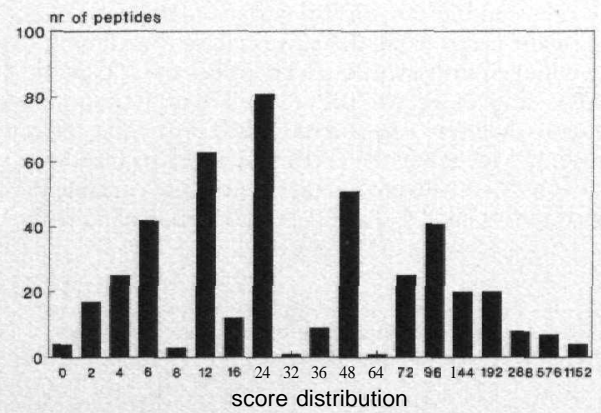

Figure 1. The score distribution for peptides of the influenza matrix protein using the computer scoring program. The maximum score for a peptide is 36864 points ( $6^{2}$ points $\times 4^{3}$ points $\times 2^{4}$ points). Peptides with an anchor residue at position 2 and the C-terminal end were used in our experiments together with 18 control peptides. 
Table 1. The Influenza matrix peptides with a high score

\begin{tabular}{|c|c|c|c|c|}
\hline $\begin{array}{l}\text { Seq. } \\
\text { nr. }\end{array}$ & score & peptides & F.R. & $t^{*}$ jblocking \\
\hline 14 & 1152 & I I P S G P L K A & 1.00 & 12 \\
\hline $\begin{array}{l}14 \\
41\end{array}$ & $\begin{array}{l}1152 \\
1152\end{array}$ & $\begin{array}{lllllllllll}I & I & P & S & G & P & I & K & A & E & I \\
V & I & M & E & W & L & K & T & R & P & I\end{array}$ & $\begin{array}{l}0.95 \\
2.79 »\end{array}$ & 67 \\
\hline 3 & 576 & L I T E V E T Y V & $2.69 *$ & 86 \\
\hline 3 & 576 & L L T E V E T Y V L & $3.11 *$ & 50 \\
\hline 51 & 576 & I L S P L T K G I & $2.73 *$ & 80 \\
\hline 51 & 576 & I L S P I T K G I L & $1.56 *$ & 63 \\
\hline 54 & 576 & P L I K G I L G F V & 0.98 & 13 \\
\hline 58 & 576 & G I L G F V F T L & $2.92 *$ & 0 \\
\hline 58 & 576 & $G I L G F V F T L T V$ & $2.14 *$ & \\
\hline 98 & 576 & K I Y R K L K R E I & 0.96 & 8 \\
\hline 106 & 576 & E I T F H G K E I & 1.05 & \\
\hline 2 & 288 & $S L I T E V E T Y V$ & $2.38 \gg$ & 80 \\
\hline 2 & 288 & S L I T E VE T Y V L & $3.51 *$ & 63 \\
\hline 50 & 288 & P I L S P I T K G I & $1.66 *$ & \\
\hline 50 & 288 & P I I S P L T K G I L & 0.98 & \\
\hline 134 & 288 & $R M G A \nabla T T E V$ & $2.12 *$ & 64 \\
\hline 134 & 288 & R M G A V T T T V V A & 0.93 & \\
\hline 218 & 288 & R I G T H P S S S A & 1.00 & \\
\hline 11 & 144 & $V I D I I P S G P L$ & 1.20 & 11 \\
\hline 19 & 144 & $P I K A \quad E I A Q R L$ & 1.06 & 10 \\
\hline 23 & 144 & E I A Q R I E D V & 1.02 & \\
\hline 23 & 144 & EAQRLEDVFA & 1.01 & \\
\hline 59 & 144 & I L G F V TLYV & $1.87 *$ & 2 \\
\hline 102 & 144 & K I K R E I T F H G A & 0.97 & 0 \\
\hline 130 & 144 & L I Y N R M G A V & 1.24 & \\
\hline 145 & 144 & $\bar{G} I V C A T C E Q I A$ & $1.83 *$ & 56 \\
\hline 145 & 144 & $G \mathrm{G} V \mathrm{C} A \mathrm{~A} C \mathrm{~B} Q \mathrm{I}$ & 1.04 & 18 \\
\hline 164 & 144 & $Q \mathrm{MVTTTNPL}$ & $3.31 *$ & \\
\hline 164 & 144 & $Q \mathrm{MVT} T \mathrm{~T} N \mathrm{P}$ I I & $1.98 *$ & \\
\hline 172 & 144 & L I R H E N R M V & 0.85 & \\
\hline 172 & 144 & L I R H E N R V V L & 0.90 & \\
\hline 172 & 144 & L I R H E N R M V L A & 1.08 & \\
\hline 191 & 144 & $Q M A G S S E Q A$ & 0.98 & 9 \\
\hline 228 & 144 & $G \mathrm{~L} K \mathrm{~K} D \mathrm{~L} \mathrm{~L} \mathrm{E} \mathrm{N} \mathrm{L}$ & 1.03 & \\
\hline
\end{tabular}

a) The sequence number fSeq. nr.) of the first amino acid is shown. The peptides are ranked according to their computer score. The fluorescence ratio (final peptide concentration in the binding assay was $100 \mu \mathrm{g} / \mathrm{ml}$ ). \% blocking of lysis using an E/Tof $5: 1 . T 2$ was the target cell line. The asterisk indicates the binding peptides. For conditions of blocking see Sect. 2.3.

Table 2. The Influenza matrix peptides with a low score

\begin{tabular}{|c|c|c|c|c|}
\hline $\begin{array}{l}\text { Seq. } \\
\text { nr. }\end{array}$ & score & peptides & & F.R. \\
\hline 13 & 72 & $D I I P S G P L K A$ & & 1.06 \\
\hline 42 & 72 & 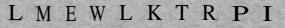 & & 1.05 \\
\hline 42 & 72 & L M E W L K T R P I & $L$ & 1.04 \\
\hline 45 & 72 & W I K T R P I L S P & $\mathrm{L}$ & 1.08 \\
\hline 114 & 72 & E I S L S Y S A G A & & 1.05 \\
\hline 114 & 72 & E I $S$ L $S$ Y $S A \in \mathbb{A}$ & L & 1.04 \\
\hline 116 & 72 & $S L S Y S A G A L$ & & 1.06 \\
\hline 116 & 72 & $S L S Y S A G A L A$ & & 1. 05 \\
\hline 123 & 72 & A L A S C M G L I & & 1.26 \\
\hline 127 & 72 & C H G L I $\quad \mathrm{Y} \quad \mathrm{N} \quad \mathrm{R} \quad \mathrm{M}$ & & 1. 14 \\
\hline 127 & 72 & C $M$ M $\quad L \quad I \quad Y \quad N \quad R \quad M \quad G$ & A & 1. 17 \\
\hline 129 & 72 & G L I I Y N $\quad \mathrm{N} \quad \mathrm{H} \quad \mathrm{G} A$ & & 1.03 \\
\hline 129 & 72 & 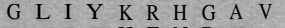 & & 1.02 \\
\hline 171 & 72 & P L I R H E N R M & & 1.05 \\
\hline 171 & 72 & 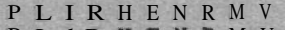 & & 0.95 \\
\hline 171 & 72 & 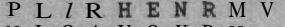 & $\mathrm{L}$ & 0.96 \\
\hline 236 & 72 & 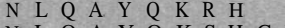 & & 1.01 \\
\hline 236 & 72 & N L Q A Y Q $\quad$ K $\quad$ S H & $\mathrm{V}$ & 0.98 \\
\hline 38 & 36 & $D$ L E V L M E W L & & 1.11 \\
\hline 65 & 36 & $T I T V P S E R G L$ & & 1.08 \\
\hline 73 & 36 & G $L \quad Q \quad R \quad R \quad R \quad F \quad V \quad Q \quad N$ & A & 1.05 \\
\hline 178 & 36 & 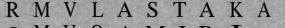 & & 1.05 \\
\hline 211 & 36 & Q M $\vee$ Q A M I R I & & 1.11 \\
\hline 180 & 24 & $V I A S T A K A M$ & & 1.08 \\
\hline
\end{tabular}

a) See footnote to Table 1 cule cell surface expression on the T2 cell line, while none of the low-scoring or control peptides did so (cut off $>1.5$ ) (Tables 1-3 column FR). The FACScan results shown in Tables 1-3 were highly reproducible. The FACScan procedure was an effective second step in finding potential CTL epitopes.

Table 3. The Influenza matrix peptides used as a control group $^{\mathrm{a}, \mathrm{b})}$

\begin{tabular}{|c|c|c|c|}
\hline $\begin{array}{l}\text { Sec. } \\
\text { nr. }\end{array}$ & peptides & F.R. & $\%$ blocking \\
\hline 20 & $L K A$ E I A Q R L & 0.98 & 2 \\
\hline 31 & V F A G K N T D L & 1.00 & 37 \\
\hline 41 & V L M E W L K T R & 1.07 & 45 \\
\hline 47 & $\begin{array}{lllllll}K & T & R & P & I & L & S\end{array}$ & 1.05 & 20 \\
\hline 55 & $I I K \in I L G F \nabla$ & 1.00 & 12 \\
\hline 60 & $\bar{L} G \bar{F} \bar{F} \mathrm{~T} T \mathrm{~V}$ & 0.95 & 22 \\
\hline 75 & QRRRF $F$ & 0.99 & 1 \\
\hline 88 & $G D P N N M D A$ & 0.97 & 15 \\
\hline 91 & $N \mathbb{N} M D K A V K L$ & 1.05 & 36 \\
\hline 95 & 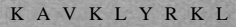 & 1.07 & 31 \\
\hline 98 & K L $\quad$ Y $\quad R \quad K \quad L \quad K \quad R \quad E$ & 0.95 & 4 \\
\hline 99 & L Y R K L K R E I & 0.99 & 8 \\
\hline 107 & I T F H G A K E I & 0.96 & 10 \\
\hline 173 & I R H B N R V L & 0.92 & 18 \\
\hline 179 & $\mathrm{M}$ V I A S T A K A & 1.09 & 20 \\
\hline 194 & $G S S E O A A E A$ & 0.97 & 2 \\
\hline 201 & $E A M E A S Q A$ & 0.98 & $1-$ \\
\hline 232 & $D L I E N L Q \vec{A} Y$ & 0.99 & 9 \\
\hline
\end{tabular}

b) The peptides are ranked according to their sequence number. 
To determine if peptides which up-regulate the HLA-A2.1 molecule actually bind to the HLA-A2.1 molecule we tested 11 binding peptides and 26 non-binding peptides for competition in a cytotoxicity assay. We expected those which up-regulate the HLA-A2.1 molecule on the T2 cell surface to block lysis of an HLA-A2.1-restricted CTL clone specific for the influenza matrix protein. The results in the last column of Tables 1 and 3 show that peptides which up-regulate HLA-A2.1 block the lysis of the CTL clone, except the peptides 58-66 and 59-68 which are recognized by the CTL clone (cut off $\geq 50 \%$ blocking).

\subsection{Effect of human $\beta_{2} m$}

The detection threshold of HLA-A2.1 up-regulation lies at a concentration of 25 to $50 \mu \mathrm{g} / \mathrm{ml}$ peptide without $\beta_{2} \mathrm{~m}$ (Fig. 2). The detection level of HLA-A2.1 up-regulation is at a concentration of 6.25 to $12.5 \mu \mathrm{g} / \mathrm{ml}$ peptide with $\beta_{2} \mathrm{~m}$ (Fig. 2). The addition of free human $\beta_{2} \mathrm{~m}$ increases the overall HLA-A2.1 cell surface expression compared to tests in which no fcm was added (Fig. 2). The sensitivity of the peptide binding assay is not further enhanced by the addition of higher concentrations ( $>20 \mathrm{ug} / \mathrm{ml}$ ) of $\beta_{2} \mathrm{~m}$ (data not shown). We conclude that human $\beta_{2} m$ increases the sensitivity of our peptide binding assay without affecting background binding. The optimal final concentration of human $\beta_{2} \mathrm{~m}$ is $15 \mu \mathrm{g} / \mathrm{ml}$.

\section{Discussion}

Peptides which bind to HLA-A2.1, if immunoreactive, might be suitable for use as vaccine components to prevent the outgrowth of tumors or pathogens which express those peptides in the context of HLA-A2.1. A number of recent studies in mice have indicated the feasibility of this approach [26-28]. Preventive peptide vaccination using a $T$ cell epitope of the lymphocytic choriomeningitis virus (LCMV)-NP can reduce the virus titer when mice are infected with LCMV [26]. Immunization of mice with a virus-specific CTL epitope derived from the Sendai virus protects them from a lethal infection [27]. Immunization with synthetic peptides derived from a tumor-inducing virus reduces the growth of these tumors [28].

The therapeutic value of CTL has been reviewed $[29,30]$. Binding peptides might be used to induce a primary CTL response using the $\mathrm{T} 2$ cell line loaded with a binding peptide as an antigen-presenting cell. A similar approach has been reported for the mouse system [31]. One of the problems might be that in vitro primed CTL stimulated with peptides might not always recognize endogenously processed antigens, in contrast to their recognition of cells sensitized with the target antigen [32]. Harty and Bevan overcame this problem by in vitro restimulation of spleen cells of mice immunized with a synthetic peptide with cells transfected with the gene encoding the epitope [33]. Using this method, high-affinity CTL clones were generated, instead of CTL clones which only recognize peptide-loaded target cells.

Human fam is required for the post-translational processing and transport of all HLA-A, -B and C gene products to the cell surface $[34,35]$. The effect of fcm in our peptide

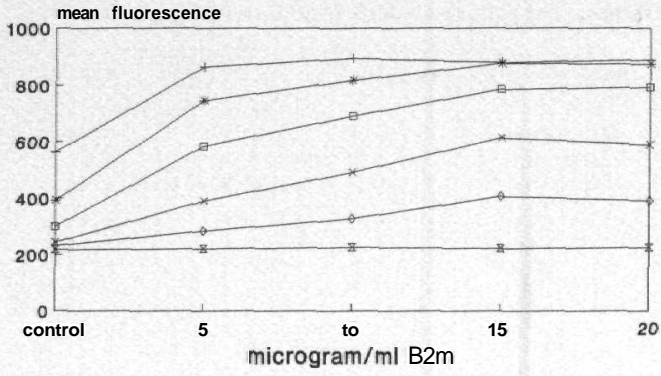

$+100 \rightarrow 50 \rightarrow 25 \rightarrow 12.5 \rightarrow 6.25 \rightarrow 0$

Figure 2. Effect of $\beta_{2} \mathrm{~m}$ on the up-regulation of HLA-A2.1 molecules on the $\mathrm{T} 2$ cell surface. $\beta_{2} \mathrm{~m}$ was used at four different concentrations $(5-10-15-20 \mathrm{ug} / \mathrm{ml})$. No $\beta_{2} \mathrm{~m}$ was used in the control test. The peptide concentrations were $100 ; 50 ; 25 ; 12.5 ; 6.25$; $0 \mu \mathrm{g} / \mathrm{ml}$ (several binding peptides were used).

binding assay can be explained in different ways. First, the addition of human $\beta_{2} \mathrm{~m}$ might increase the number of peptide binding sites on the cell surface, for example by rescue of free heavy chains from dissociation. In that case the HLA molecules remain available for peptide acquisition. Indeed, Boyd et al. showed that the number of high affinity binding sites increased when $\beta_{2} \mathrm{~m}$ was used together with purified soluble analogues of MHC molecules [36]. Second, $\beta_{2} \mathrm{~m}$ may selectively bind to the heavy chain which is already stabilized by a binding peptide [37]. Finally, Otten et al. reported that when the fern-heavy chain complex begins to dissociate it would become more accessible to peptide binding [38]. The number of HLA-A2.1 molecules on the cell surface of the T2 cell line does not increase when $\beta_{2}$ m is used (maximum $\beta_{2}$ m concentration 20 $\mu \mathrm{g} / \mathrm{ml}$ ) without a peptide or a non-binding peptide (see Fig. 2 at peptide concentration of $0 \mathrm{ug} / \mathrm{ml}$ ).

One may expect that furtherrefinements of the HLA-A2.1 peptide motif will be possible in the near future. The peptide motif does not take into account that flanking amino acids of the presented peptide might influence the processing and presentation of peptides [39]. Therefore, not all binding peptides are likely to be processed in vivo. On the other hand most naturally processed self peptides and viral epitopes conform to the motif.

Peptide sequences that potentially trigger HLA-A2.1restricted CTL can be easily detected using our test system. Our computer scoring program in combination with the peptide binding assay can be used for other HLA molecules. For that purpose one requires a peptide motif, T2 cells transfected with the specific HLA-allele and a monoclonal antibody specific for that HLA molecule. The HLA-A2.1 molecule is present in $40 \%$ of the Western European Caucasoid population. Thus, in principle those individuals could benefit from treatment with tumorspecific CTL or tumor-associated peptides.

We thank Dr. F. Koning and Dr. P. Schrierfor critically reading this manuscript.

Received October 10. 1992; in revised form February 11, 1993. 


\section{References}

1 Townsend, A. and Bodmer. H., Annu. Rev. Immunol. 1989. 7: 601.

2 Bjorkman, P. J., Saper, M. A., Samraoui, B., Bennet, W. S., Strominger, J. L. and Wiley, D. C, Nature 1987. 329: 506.

3 Dobberstein, B., Garoff, H. Warren, G. and Robinson, P. J., Cell 1979. 17: 759 .

4 Townsend, A., Öhlen, C. Bastin, J., Ljunggren, H. G.. Foster, L. and Karre, K.. Nature 1989. 340: 443.

5 Arce-Gomez, B., Jones, E. A., Barnstable, C. J., Solomon, E. and Bodmer, W. E, Tissue Antigens 1978. 11: 96.

6 Ploegh, H. L., Orr, H. T. and Strominger, J. L., Cell 1981. 24 : 287.

7 Seong, R. H., Clayberger, C. A., Krensky, A. M. and Parnes, J. R., J. Exp. Med. 1988. 167: 288.

8 Rötzschke, O., Falk, K., Deres, K., Schild, H.. Norda, M., Metzger, J., Jung, G. and Rammensee, H., Nature 1990. 34S: 252

9 Van Bleek, G. M. andNathenson, S. G., Proc. Natl. Acad. Sci. USA 1991. 88: 11032.

10 Nuchtern, J. G., Bonifacino, J. S., Biddison, W. E. and Klausner, R. D.. Nature 1989. 339: 223.

11 Yewdell, J.W and Bennink, J. R.. Science 1989. 244: 1072.

12 Yewdell, J.W. and Bennink. J. R., Cell 1990. 62; 203.

13 Kvist, S. and Hamann, U., Nature 1990. 348: 446.

14 DeMars, R. Chang, C. C, Shaw, S., Reitnauer, P. J. and Sondel, P. M.. Hum. Immunol. 1984. 11: 77.

15 Salter, R. D. and Cresswell, P., EMBOJ. 1986. 5: 943.

16 Hosken, N. A. and Bevan, M. J., Science 1990. 24S: 367

17 DeMars, R. and Spies, T., Trends in Cell Biol. 1992. 2: 81

18 Henderson, R. A., Michel, H., Sakaguchi, K., Shabanowitz. J. Appella, E. Hunt, D. F. and Engelhard, V.H.. Science 1992. 255: 1264 .

19 Wei, M. L. and Cresswell, P, Nature 1992. 356: 443.

20 Hunt. D. F., Henderson, R. A., Shabanowitz, J., Sakaguchi. K., Michel. H., Sevilir, N.. Cox, A. L., Appella, E. and Engelhard, V. H., Science 1992. 255; 1261.

21 Cerundolo, B.. Alexander, J., Anderson, K., Lamb, C, Cresswell, P., McMichael, A.. Gotch, F. and Townsend, A., Nature 1990. 345: 449.
22 Falk, K., Rötzschke. O.. Stevanovic, S., Jung. G. and Rammensee, H. G., Nature 1991. 351: 290

23 Winter. G. and Fields, S., Nucleic Acids Res. 1980. 8: 1965.

24 Morrison, J., Elvin, J.. Latron, F., Gotch. E, Moots, R. Strominger. J. L. and McMichael, A., Eur. f Immunol. 1992 22:903.

25 Deres, K., Schumacher, T. N. M., Wiesmüller, K. H.. Stevanovic, S., Greiner, G., Jung, G. and Ploegh, H. L., Eur. J. Immunol. 1992. 22: 1603.

26 Schulz, M., Zinkernagel, R. M. and Hengartner, H., Proc. Natl. Acad. Sci. USA 1991. SS: 991.

27 Kast,W. M., Roux, L.. Curren. J., Blom, H. J. J., Voordouw, A C. Meloen, R. H.. Kolakofsky, D. and Melief, C. J. M., Proc. Natl. Acad. Sci. USA 1991. 88: 2283.

28 Reinholdsson-Ljunggren, G., Ramqvist, T., Ährlund-Richter, L. and Dalianis, T., Int. J. Cancer 1992. SO: 142.

29 Kast, W. M. and Mellief, C. J. M.. Immunol. Lett. 1991. 30 292.

30 Melief, C. J. M., Adv. Cancer Res. 1992. 58: 143.

31 De Bruijn, M. L. H., Schumacher. T. N. M.. Nieland. J. D. Ploegh, H. L., Kast, W. M. and Melief, C. J. M., Eur. J. Immunol. 1991. 21: 2963.

32 Schild, H., Norda, M., Deres, K., Falk, K., Rötzschke, O., Wiesmüller, K. H.. Jung, G. and Rammensee, H. G.. J. Exp. Med. 1991. 174: 1665.

33 Harty, J. T. and Bevan, M. J., J. Exp. Med. 1992. f75: 1531.

34 Neefjes, J. J. and Ploegh, H. L.. Eur. J. Immunol. 1988. 18. 801.

35 Hochman, J. H.. Shimizu, Y., DeMars, R. and Edidin, M., J. Immunol. 1988. 140: 2322.

36 Boyd, L. E, Kozlowski, S. and Margulies, D. H., Proc. Natl. Acad. Sci. USA 1992. 89: 2242.

37 Townsend, A., Elliot, T.. Cerundolo, V., Foster, L., Barber, B. and Tse. A., Cell 1990. 62: 285.

38 Otten. G. R., Bikoff, E., Ribaudo, R. K., Koziowski, S., Margulies, D. H. and Germain, R. N.. J. Immunol. 1992. 148. 3723.

39 Del Val, M., Schlicht, H. J.. Ruppert, T., Reddehase, J. and Koszinowski, U. H., Celt 1991. 66: 1145. 